KREATIF Jurnal IImiah
@Prodi Manajemen Fakultas Ekonomi Universitas Pamulang ISSN : $2339-0689$, E-ISSN : 2406-8616

J. KREATIF, Vol. 9 No. 1, Juni 2021 (Halaman 37-49)

Tersedia Online di :http://openjournal.unpam.ac.id/index.php/kreatif

\title{
PENGARUH KEPEMIMPINAN KERJA DAN LINGKUNGAN KERJA TERHADAP TURNOVER INTENTION KARYAWAN PADA PT VANISA RIZKI JAKARTA SELATAN
}

\author{
${ }^{1}$ Feb Amni Hayati, ${ }^{2}$ Uswatun Chasanah, ${ }^{3}$ Anis Surya Ningsih \\ ${ }^{1,2}$ Dosen dan ${ }^{3}$ Alumni Program Studi Manajemen Fakultas Ekonomi Universitas Pamulang \\ Emai: dosen01657@unpam.ac.id, dosen2021@unpam.ac.id
}

\begin{abstract}
ABSTRAK
Penelitian ini bertujuan untuk mengetahui pengaruh kepemimpinan kerja dan lingkungan kerja terhadap Turnover Intention karyawan pada PT Vanisa Rizki di Jakarta Selatan baik secara parsial maupun simultan

Metode yang digunakan dalam penelitian ini yaitu metode diskriptif kuantitatif, yaitu metode penelitian yang memberikan gambaran mengenai suatu masalah yang terjadi pada saat penelitian berlangsung, meliputi data yang dikumpulkan, kemudian dibahas, diolah dan dianalisis, sehingga dapat dicari alternatif pemecahan masalahnya. Metode pengumpulan data yang dilakukan dalam penelitian ini diantaranya observasi dan penyebaran kuesioner atau angket. Sampel yang digunakan dalam penelitian ini adalah teknik sampel jenuh, yang merupakan teknik penentuan sampel apabila semua anggota populasi digunakan sebagai sampel. Anggota populasi sebagai responden dengan jumlah karyawan pada PT. Vanisa Rizki yang berjumlah 50 orang.

Berdasarkan hasil perhitungan secara parsial antara kedua variabel bebas yang masing masing memiliki hasil sebagai berikut : tidak terdapat Pengaruh Kepemimpinan Kerja terhadap Turnover Intention Karyawan pada PT. Vanisa Rizki dengan perhitungan t hitung $=0,614<\mathrm{t}$ tabel $=2,012$ yang diperoleh taraf signifikasi $(\alpha)$ sebesar 0,542 $>0,05$ maka Ho1 diterima dan Hal ditolak. Selanjutnya terdapat Pengaruh antara Lingkungan Kerja terhadap Turnover Intention Karyawan pada PT. Vanisa Rizki dengan perhitungan t hitung $=11,860>\mathrm{t}$ tabel $=2,012$ yang diperoleh taraf signifikasi $(\alpha)$ sebesar $0,000<0,05$ maka Ho2 ditolak dan Ha2 diterima. Berdasarkan analisis hasil perhitungan data pengaruh antara variabel bebas Kepemimpinan Kerja (X1) dan variabel Lingkungan Kerja (X2) terhadap variabel terikat Turnover Intention Karyawan (Y) pada PT. Vanisa Rizki ditujukkan pada regresi linier berganda $\mathbf{Y}=\mathbf{6 , 3 7 7}+\mathbf{0 , 0 6 4} \mathbf{X}_{\mathbf{1}}+\mathbf{0 , 7 6 1} \mathbf{X}_{\mathbf{2}}$, koefisien $r=0,866$, nilai koefisien Adjusted $\mathrm{R}$ square $\mathrm{R}=0,750$ atau 75\% dan nilai $\mathrm{F}$ hitung $=70,361>$ nilai $\mathrm{F}$ tabel $=$ 3,19. Sehingga dapat diartikan terdapat Pengaruh yang signifikan antara Kepemimpinan Kerja $\left(\mathrm{X}_{1}\right)$ dan Lingkungan Kerja $\left(\mathrm{X}_{2}\right)$ terhadap Turnover Intention Karyawan pada PT. Vanisa Rizki Jakarta Selatan.
\end{abstract}

Kata Kunci : Kepemimpinan Kerja, Lingkungan Kerja dan Turnover Intention Karyawan

\section{ABSTRAK}

This study aims to look at work leadership and work environment at PT Vanisa Rizki in South Jakarta. To depart from Intention at PT Vanisa Rizki in South Jakarta, and to find out the influence of Work Leadership and Work Environment on Turnover Intention at PT Vanisa Rizki, South Jakarta.

The method used in this research is quantitative method, which means that this research is limited to uncovering a problem and trying to find a solution or problem of an existing problem. The data method used in this research is observation, among others, and distributing questionnaires or questionnaires. The sample used in this study is the saturated sampling technique, which is a technique of determining the sample of all members of the 
population used as a sample. Members of the respondent population as the number of employees at PT. Vanisa Rizki who assessed 50 people.

Based on the results of partial calculations between the two independent variables, each of which has the following results: there is no influence of Work Leadership on Employee Turnover Intention at PT. Vanisa Rizki with the calculation of t count $=0.614$ $<t$ table $=2.012$ which obtained a significance level $(\alpha)$ of $0.542>0.05$ then Hol is accepted and Hal is rejected. Furthermore, there is the Influence of Work Environment Effect on Employee Turnover Intention at PT. Vanisa Rizki with the calculation of $t$ count $=11.860>t$ table $=2.012$ which obtained a significance level $(\alpha)$ of $0.000<0.05$ then $\mathrm{Ho} 2$ is rejected and Ha2 is accepted. Based on the analysis of the results of the calculation of the influence data between the independent variable Work Leadership (X1) and the Work Environment variable (X2) on the dependent variable Employee Turnover Intention (Y) at PT. Vanisa Rizki is shown in multiple linear regression $Y=6.377+0.064 X 1+0.761 X 2$, the coefficient $r=0.866$, the value of the Adjusted $R$ square coefficient $R=0.750$ or $75 \%$ and the calculated $F$ value $=70.361>F$ table value $=3.19$. So it can be interpreted that there is a significant influence between Work Leadership (X1) and Work Environment (X2) on Employee Turnover Intention at PT. Vanisa Rizki, South Jakarta.

Keywords: Work Leadership, Work Environment and Employee Turnover Intention

\section{PENDAHULUAN}

\section{Latar Belakang Masalah}

Sumber daya manusia memiliki peranan penting dalam perusahaan yang tidak dapat terpisahkan dalam pencapaian tujuan perusahaan. Sumber daya manusia (SDM) merupakan pelaksanaan dalam perusahaan yang akan mengelola dan memanfaatkan unsur-unsur seperti mesin, modal, bahan baku di dalam perusahaan sehingga nantinya unsur - unsur tersebut dapat dimanfaatkan secara efektif dan efisien. Hal ini menandakan bahwa diperlukan adanya proses pengelolaan sumber daya manusia yang baik di dalam suatu perusahaan guna mencapai tujuan perusahaan.

Untuk mendapatkan SDM yang handal dan memenuhi kualifikasi keahlian yang diperlukan seringkali perusahaan harus mengadakan training atau pelatihan yang memakan biaya yang cukup besar dan menyita waktu yang cukup lama. Seringkali perusahaan dihadapkan pada permasalahan bahwa karyawan yang telah mendapat pelatihan dan mulai menguasai pekerjaanya dengan baik berkeinginan untuk pindah kerja (turnover intention) yang berujung pada keputusan karyawan untuk meninggalkan pekerjaan.

Turnover dapat menjadi masalah besar bagi perusahaan jika tidak mendapatkan perhatian yang serius. Selain kerugian dari sisi biaya yang telah dikeluarkan perusahaan dalam penyelenggaraan pelatihan, perusahaan juga mengalami kerugian dari sisi efesiensi waktu dan hilangnya sumberdaya manusia yang telah menguasai pekerjaannya. Pergantian karyawan baru imbas dari turnover selain akan menyebabkan menurunnya produktifikas juga menimbulkan beberapa efek ikutan terkait efesiensi waktu kerja, kualitas pekerjaan, dan hubungan kerja.

Turnover sebagian besar disebabkan ketidakpuasan dan ketidaknyamanan karyawan dalam bekerja. Ketiadakpuasan bisa berasal dari hal-hal yang bersiat fisik seperti lingkungan kerja, sarana prasarana dan fasilitas, juga bisa berasal dari hal-hal yang bersifat non fisik, seperti kepemimpinan, hubungan kerja dan lain-lain.

Sebagai data pendukung, penulis telah mengambil data turnover intention dari PT Vaniza Rizki sebagai berikut : 
Tabel 1.1 Data Turnover Intention Karyawan

PT Vaniza Rizki

\begin{tabular}{|c|c|c|c|}
\hline NO & Nama Jabatan & $\mathbf{2 0 1 8}$ & $\mathbf{2 0 1 9}$ \\
\hline 1 & Operational & 1 & 1 \\
\hline 2 & Courir & 2 & 1 \\
\hline 3 & Formalities & 5 & 7 \\
\hline 4 & Administrator & 2 & - \\
\hline 5 & IT Staff & 1 & 1 \\
\hline 6 & Finance Staff & 1 & 2 \\
\hline
\end{tabular}

Sumber ; PT Vaniza Rizki

Dari data diatas dapat dilihat bahwa karyawan PT Vanisa Rizki mengalami fase keluar masuknya karyawan baru maupun karyawan yang telah lama bekerja pada periode 2018 - 2019. Dari data tersebut dapat dilihat tingkat turnover yang tinggi, yaitu 12 karyawan pada tahun 2018 dan 12 karyawan juga pada tahun 2019. Artinya pada tahun 2018 dan 2019 terjadi turnover karyawan yang sama banyaknya. Hal tersebut memperlihatkan adanya ketidakpuasan karyawan yang berimbas pada turnover karyawan. Dan dari tahun 2018 sampai tahun 2019 perusahaan tidak mengganggap hal itu sebagai sesuatu yang penting sehingga tidak ada segmen yang diperbaiki untuk meningkatkan kepuasan dan kenyamanan karyawan yang dapat menurunkan tingkat turnover karyawan.

Kepemimpinan merupakan salah satu faktor penting dalam memberikan kenyamanan dan kepuasan karyawan dalam bekerja. Kepemimpinan yang baik dapat memberikan pengarahan, memotivasi, memberdayakan karyawan dan juga memberikan teladan yang baik kepada karyawan-karyawannya. Sehingga karyawan dapat menjalankan tugasnya dengan nyaman, percaya diri, dan bertanggungjawab. Baik dalam melaksanakan pekerjaan secara individual maupun bekerja dlam kelompok secara efektif, efesien dan berkelanjutan.

Salah satu tantangan yang cukup berat yang sering harus dihadapi oleh pemimpin adalah bagaimana ia dapat menggerakkan para bawahannya agar senantiasa mau dan bersedia mengerahkan kemampuannya yang terbaik untuk kepentingan kelompok atau organisasinya. Seringkali kita menjumpai adanya pemimpin yang menggunakan kekuasaannya secara mutlak dengan memerintahkan para bawahannya tanpa memperhatikan keadaan yang ada pada bawahannya. Hal ini jelas akan menimbulkan suatu hubungan yang tidak harmonis dalam organisasi.

Di lain pihak, segala sesuatu yang berada di sekitar karyawan juga dapat memper=ngarugi dirinya dalam menjalankan tugas-tugasnya. Dengan lingkungan yang rapi, bersih dan nyaman membuat karyawan lebih semangat dalam bekerja, tidak mudah sakit, mudah berkonsentrasi sehingga pekerjaan dapat diselesaikan denga eektif dan efesien sesuai dengan tujuan perusahaan. Sebaliknya kondisi lingkungan kerja yang tidak sehat dapat menyebabkan karyawan mudah stress, tidak semangat untuk bekerja dan datang terlambat.

Sebagai data pendukung, penulis telah melalukan prasurvei kepada 10 karyawan PT. Vanisa Rizki yang diambil secara acak. Hasilnya dapat dilihat pada table berikut : 
Tabel 1.2

Data Prasurvei tentang Kepemimpinan Kerja

\begin{tabular}{|c|c|c|c|c|c|}
\hline $\begin{array}{l}\text { R } \\
\text { E } \\
\text { S } \\
\text { P } \\
\text { O } \\
\text { N } \\
\text { D } \\
\text { E } \\
\text { N }\end{array}$ & $\begin{array}{l}\text { Kemampuan } \\
\text { Untuk Membina } \\
\text { Kerjasama Dan } \\
\text { Hubungan Yang } \\
\text { Baik }\end{array}$ & $\begin{array}{l}\text { Kemampuan } \\
\text { Untuk } \\
\text { Efektivitas }\end{array}$ & $\begin{array}{l}\text { Kepemimpinan } \\
\text { Yang Partisipatif } \\
\text { (Pengambilan } \\
\text { Keputusan Secara } \\
\text { Musyawarah Dan } \\
\text { Dapat } \\
\text { Menyelesaikan } \\
\text { Masalah Secara } \\
\text { Tepat) }\end{array}$ & $\begin{array}{l}\text { Kemampuan } \\
\text { Dalam } \\
\text { Mendelegasikan } \\
\text { Tugas Atau } \\
\text { Waktu }\end{array}$ & $\begin{array}{l}\text { Kemampuan } \\
\text { Dalam } \\
\text { Mendelegasikan } \\
\text { Tugas Dan } \\
\text { Wewenang }\end{array}$ \\
\hline 1 & Kurang Baik & Kurang Baik & Kurang Baik & Kurang Baik & Kurang Baik \\
\hline 2 & Kurang Baik & Kurang Baik & Kurang Baik & Kurang Baik & Kurang Baik \\
\hline 3 & Baik & Baik & Baik & Baik & Baik \\
\hline 4 & Baik & Baik & Kurang Baik & Baik & Baik \\
\hline 5 & Baik & Baik & Kurang Baik & Baik & Baik \\
\hline 6 & Baik & Baik & Baik & Baik & Baik \\
\hline 7 & Baik & Baik & Baik & Baik & Baik \\
\hline 8 & Baik & Baik & Baik & Baik & Baik \\
\hline 9 & Baik & Kurang Baik & Kurang Baik & Baik & Baik \\
\hline 10 & Baik & Baik & Kurang Baik & Baik & Baik \\
\hline * & $\begin{array}{l}\text { Baik = } \\
\text { Responden }\end{array}$ & \begin{tabular}{|l|} 
Baik $=7$ \\
Responden
\end{tabular} & $\begin{array}{l}\text { Baik = } \\
\text { Responden }\end{array}$ & $\begin{array}{l}\text { Baik = } \\
\text { Responden }\end{array}$ & Baik $=8$ Responden \\
\hline * & $\begin{array}{l}\text { Kurang Baik = } 2 \\
\text { Responden }\end{array}$ & $\begin{array}{lr}\text { Kurang } & \text { Baik } \\
= & 3 \\
\text { Responden }\end{array}$ & $\begin{array}{l}\text { Kurang Baik }=6 \\
\text { Responden }\end{array}$ & $\begin{array}{l}\text { Kurang Baik = } 2 \\
\text { Responden }\end{array}$ & $\begin{array}{l}\text { Kurang Baik }=2 \\
\text { Responden }\end{array}$ \\
\hline
\end{tabular}

Sumber : PT. Vaniza Rizki

Dari data prasurvei tersebut dapat dilihat hasil jawaban dari karyawan PT Vanisa Rizki tentang kepemimpinan di PT. Vaniza Rizki. Hasil yang didapatkan adalah masih kurangnya partisipasi pemimpin perusahaan dalam pengambilan keputusan secara musyawarah dan penyelesaian masalah secara tepat.

Untuk data lingkungan kerja, penulis memperoleh data pendukung berupa foto sebagai berikut :

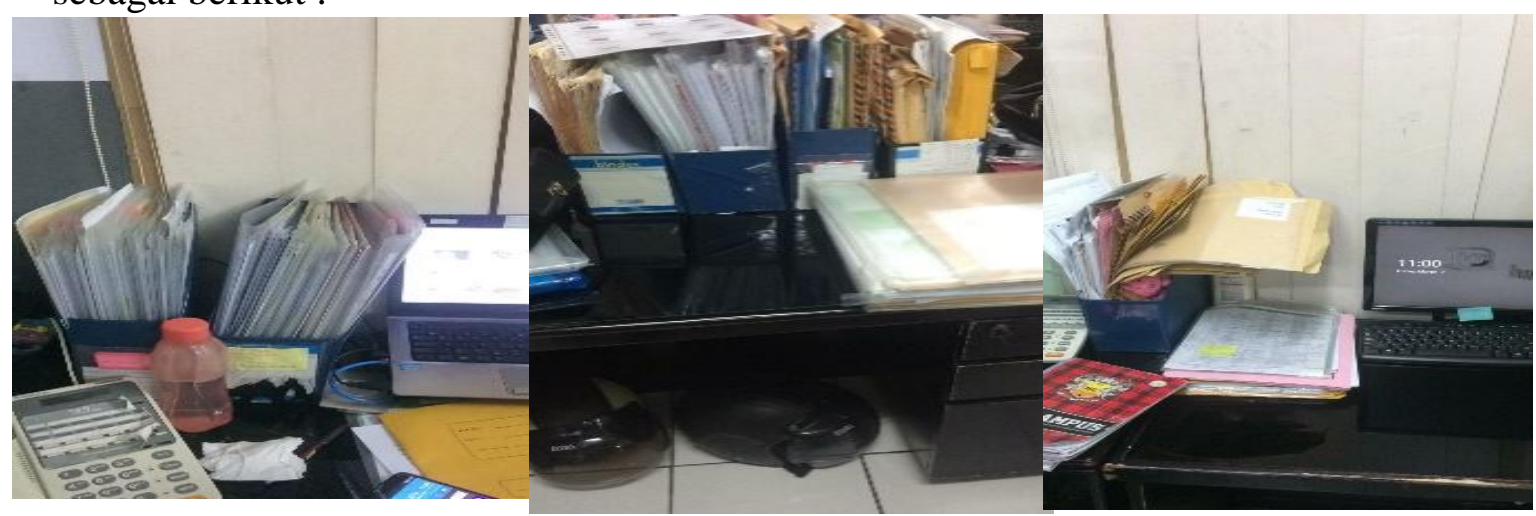

Gambar 1 : Foto Lingkungan Kerja PT. Vaniza Rizki

Berdasarkan foto diatas dapat dilihat bahwa kondisi lingkungan kerja di PT. Vaniza Rizki yang belum tertata dengan baik, file dan arsip kantor masih berantakan karena tidak ada tempat penyimpanan khusus untuk file. Penyimpanan dokumen seringkali dianggap sepele oleh perusahaan, karena diasumsikan jarang untuk digunakan. Padahal dengan 
dokumen yang tertata dengan baik dan disusun di penyimpanan khusus dapat mempermudah dalam pencarian dokumen saat dibutuhkan dan pekerjaan menjadi jauh lebih efektif.

\section{Tujuan Penelitian}

Sejalan dengan kondisi tersebut maka penulis tertarik untuk melakukan penelitian lebih dalam lagi pada perusahaan dengan judul "Pengaruh Kepemimpinan Kerja dan Lingkungan Kerja Terhadap Turnover Intention Karyawan Pada PT Vanisa Rizki Jakarta Selatan" dengan tujuan sebagai berikut :

1. Untuk mengetahui bagaimana pengaruh kepemimpinan kerja terhadap turnover intention pada PT. Vaniza Rizki Jakarta Selatan.

2. Untuk mengetahui bagaimana pengaruh lingkungan kerja terhadap turnover intention pada PT. Vaniza Rizki Jakarta Selatan.

3. Untuk mengetahui seberapa besar pengaruh kepemimpinan kerja dan lingkungan kerja terhadap turnover intention pada PT. Vaniza Rizki Jakarta Selatan.

\section{KAJIAN PUSTAKA \\ Turnover Intention}

Ronald dan Mikha (2014) mengutarakan, Turnover Intention (keinginan berpindah kerja) merupakan kecenderungan atau intensitas individu untuk meninggalkan organisasi dengan berbagai alasan dan diantaranya keinginan untuk mendapatkan pekerjaan yang lebih baik. Perputaran (turnover) dikelompokkan ke dalam beberapa cara yang berbeda, antara lain:

1. Perputaran secara tidak sukarela : berupa pemecatan (PHK) karena kinerja yang buruk dan pelanggaran peraturan kerja.

2. Perputaran secara sukarela : dimana karyawan meninggalkan perusahaan karena keinginannya sendiri.

Turnover Intention tidak terjadi karena tanpa alasan atau faktor yang mendorongnya. Seseorang tidak akan meninggalkan organisasi/perusahaan tanpa suatu faktor yang memicu timbulnya keinginan untuk berpindah/turnover intention.

Berikut adalah indikator yang digunakan untuk mengukut turnover intention menurut Chen dan Francesco dalam Dharma (2013:4) :

1. Pemikiran untuk keluar

2. Keinginan untuk mencari lowongan

3. Adanya keinginan untuk meinggalkan organisasi

\section{Kepemimpinan}

Kepemimpinan merupakan seni memotivasi dan mempengaruhi sekelompok atau orang untuk bertindak mencapai tujuan bersama (Wukir, 2013:134). Teori kepemimpinan umumnya berupaya memberi paparan atau penjelasan terkait pemimpin dan kepemimpinan dengan cara mengemukakan berbagai segi. Misalnya latar belakang sejarah sang pemimpin beserta dengan kepemimpinannya. Adapun, berikut 3 teori kepemimpinan menurut para ahli

1. Teori Sifat

Berdasar atas pemikiran bahwa keberhasilan pemimpin tergantung dengan sifatnya, ciri khas yang dimiliki, dan perangainya. Maka untuk menjadi pemimpin yang sukses dibutuhkan kemampuan pribadi seorang pemimpin. Kemampuan pribadi yang dimaksud tidak lain berupa kualitas dengan berbagai sifat, citi dan perangainya.

2. Teori Perilaku

Berdasar atas kepemimpinan yang merupaka perilaku individu saat menjalankan kegiatan mengarahkan atau membimbing kelompol tertentu guna mencapai tujuan. Dalam hal ini seorang pemimpin memiliki beberapa deskripsi perilaku. Mulai dari seorang pemimpin yang cenderung mengutamakan bawahan, bersikap ramah, mendukung, membela, mau mendengarkan, mau berkonsultasi dan memikirkan 
kesejahteraan kelompoknya. Namun, ada pula seorang pemimpin yang berorientasi pada bawahan atau produksi. Yang ditantai dengan penekanan segi teknis pekerjaan.

3. Teori Situasional

Sukses tidaknya kepemimpinan seseorang pemimpin ditentukan oleh ciru kepemimpinannya itu sendiri. Misalnya dengan berperilaku yang sesuai dengan tuntunan situasi organisasional dan situasi kepemimpinan yang dihadapi tentu dengan mempertimbangkan factor ruang dan waktu. Situasiyang dijadikan sebagai factor penentu keputusan. Menurut para ahli, watak pemimpin situasional lebih mudah menentukan keberhasilannya dibandingkan dengan watak yang hanya berfokis pada perencanaan.

Menurut Rivai (2012:53) yang menjadi indikator-indikator dari kepemimpinan kerja adalah sebagai berikut :

1. Kemampuan untuk membina kerjasama dan hubungan yang baik

2. Kemampuan yang efektivitas

3. Kepemimpinan yang partisipatif

4. Kemampuan dalam mendelegasikan tugas atau waktu

5. Kemampuan dalam mendelegasikan tugas atau wewenang

\section{Lingkungan Kerja}

Lingkungan kerja adalah segala sesuatu yang ada disekitar karyawan dan dapat mempengaruhi dalam menjalankan tugas yang dibebankan kepadanya, mialnya dengan adanya air conditioner (AC), penerangan yang memadai dan sebagainya (Nitisemito dalam Nuraini, 2013:97). Menurut Sedarmayanti (2011:21), secara garis baesar, jenis lingkungan kerja dibagi menjadi 2 yakni :

1. Lingkungan Kerja Fisik

2. Lingkungan Kerja non Fisik

Masalah lingkungan kerja dalam suatu organisasi sangatlah penting, dalam hal ini diperlukan adanya pengaturan maupun penataan faktor- faktor lingkungan kerja dalam penyelenggaraan aktivitas organisasi.

Adapun indikator-indikator di Lingkungan Kerja menurut Sedarmayanti (2011:28), adalah sebagai berikut :

1. Penerangan

2. Suhu udara

3. Suara bising

4. Penggunaan warna

5. Ruang gerak yang diperlukan

6. Keamanan

7. Hubungan karyawan

Berdasarkan beberapa teori dan pengertian diatas, maka penulis menggabungkan ketiga variable tersebut menjadi kerangka berpikir yang dijadikan pedoman dalam penelitian. Berikut merupakan bagan dari kerangka berpikir : 


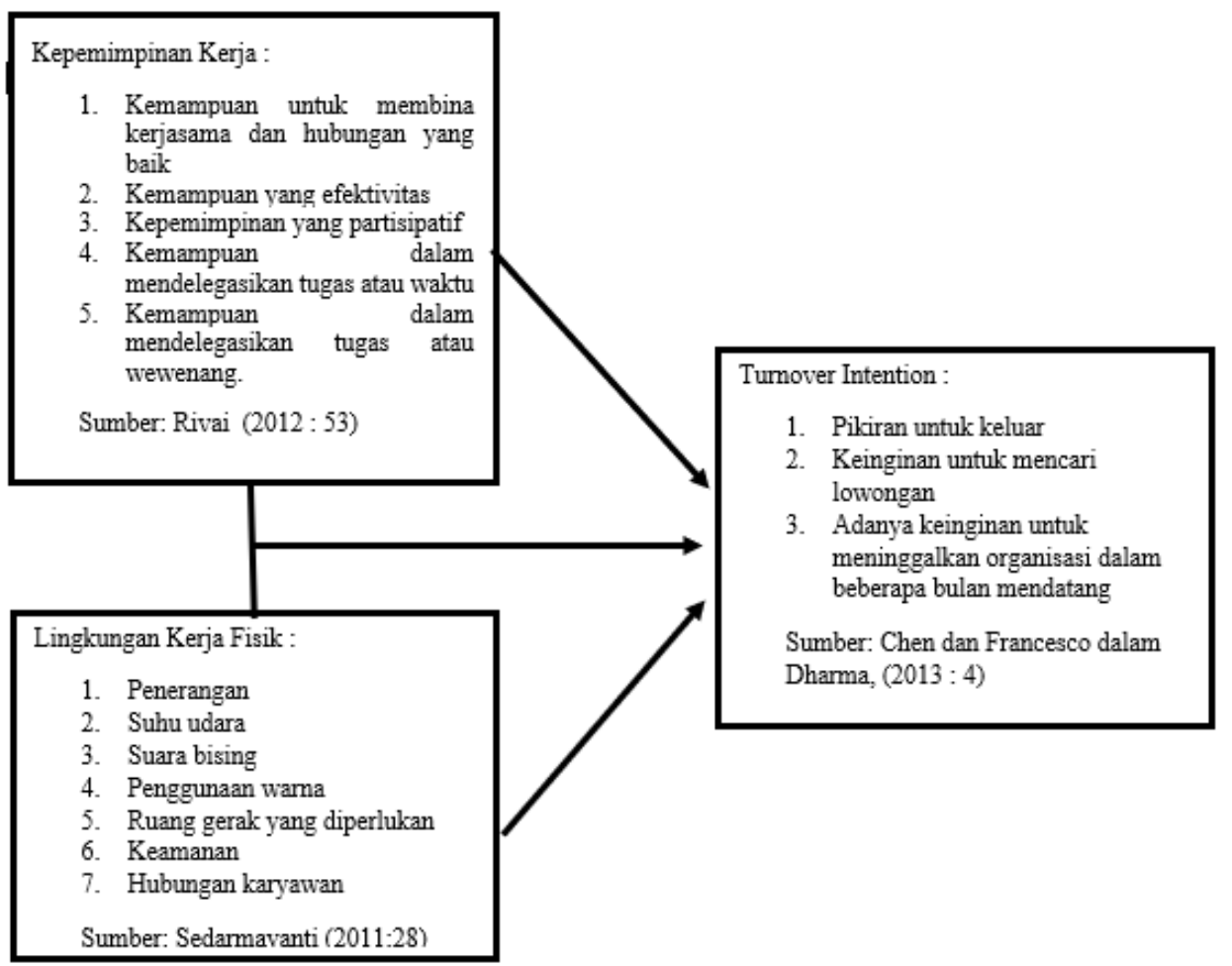

\section{METODE PENELITIAN \\ Tempat dan Waktu Penelitian}

Gambar 2. Kerangka Pemikiran

Penelitian ini dilakukan di PT. Vaniza Rizki yang beralamat di Jl Warung Buncit Raya No 62, yang merupakan perusahaan swasta yang bergerak dibidang formalities services atau jasa yang khususnya perijinan kerja dan perijinan tinggal orang asing di Indonesia. Penelitian ini dilaksanakan selama 6 (enam) bulan yang dimulai sejak bulan September 2020 sampai dengan bulan Februari 2021. Adapun penelitian ini dilakukan secara bertahap disesuaikan dengan tingkat kebutuhan penulis, sejak pra survey, kajian Pustaka sesuai dengan variabelvariabel yang diteliti, Menyusun proposal, menyebar kuesioner, analisis data, pengolahan data dan penulisan laporan penelitian.

\section{Metode Penelitian}

Pendekatan Penelitian. Pendekatan penelitian yang digunakan dalam penelitian ini adalah menggunakan metode assosiatif kuantitatif yang artinya penelitian yang bertujuan untuk mengetahui pengaruh ataupun juga hubungan antara dua variabel atau lebih. (Sugiono, 2013:11). Dengan penelitian asosiatif ini maka dapat dibangun suatu teori yang berfungsi untuk menjelaskan, meramalkan dan mengontrol suatu gejala. Data dalam penelitian diambil dari seluruh karyawan PT. Vaniza Rizki yang berjumlah 50 orang. Data yang dibutuhkan dalam penelitian ini digolongkan menjadi dua yaitu;

1. Data primer adalah data yang langsung diperoleh dari subjek penelitian dalam bentuk verbal atau ucapan lisan dan perilaku subjek (narasumber penelitian) yang berkaitan dengan relevansi kompetensi (Sugiyono, 2012)

2. Data sekunder adalah data yang digunakan untuk mendukung data primer berupa dokumen, foto, dan catatan lain yang dapat dipakai sebagai sumber data (Sugiyono, 2012).

Teknik Pengambilan Sampel Teknik pengambilan sampel dalam penelitian ini dilakukan dengan cara Interview (wawancara), Angket (Kuesioner), Observasi 
Analisa data dalam penelitian ini dilakukan dengan cara Statistik deskriptif, Uji Kualitas Data, Analisis Data.

\section{HASIL PENELITIAN}

Dalam pembahasan ini dijelaskan pengaruh masing-masing variabel bebas yaitu kepemimpinan dan lingkungan kerja terhadap variabel terikat yaitu Turnover Intention.

Tabel 4.1

Hasil Uji Reliabilitas Data

\begin{tabular}{|l|l|l|l|}
\hline Variabel & $\begin{array}{l}\text { Number } \\
\text { of Item }\end{array}$ & $\begin{array}{l}\text { Cronbach } \\
\text { Alpha }\end{array}$ & Kesimpulan \\
\hline Kepemimpinan & 10 & 0,885 & Reliable \\
\hline $\begin{array}{l}\text { Lingkungan } \\
\text { Kerja }\end{array}$ & 10 & 0,764 & Reliable \\
\hline $\begin{array}{l}\text { Turnover } \\
\text { Intention }\end{array}$ & 10 & 0,640 & Reliable \\
\hline
\end{tabular}

Sumber : Data Primer diolah, 2021

Berdasarkan table didapatkan hasil bahwa variabel Kepemimpinan memiliki nilai 0,885, variabel Lingkungan Kerja dengan nilai 0,764 dan variabel Turnover Intention dengan nilai 0,640 adalah reliabel, sehingga 3 variabel Kepemimpinan, Lingkungan Kerja dan Turnover Intention adalah stabil dan konsisten. Atau dapat dikatakan bahwa penelitian ini memiliki konsistensi dimana responden menjawab seluruh pertanyaan dengan baik.

\section{Hasil Uji Asumsi Klasik}

Pada teknis analisis regresi berganda maka digunakan uji asumsi klasik untuk memastikan bahwa pada model regresi tidak terjadi berbagai penyimpangan baik normalitas, heteroskedastisitas dan multikoliniearitas.

\section{Uji Normalitas}

Uji Normalitas digunakan untuk menguji distribusi data yang akan dianalisis menyebar normal. Uji Normalitas bermaksud untuk menguji apakah data yang digunakan dalam penelitian memiliki distribusi normal, baik secara multivarian maupun univarian.

Berikut hasil uji normalitas pada plot P-P yang normalitasnya dapat di deteksi dengan penyebaran dengan melihat data (titik) pada sumbu diagonal grafik atau dengan melihat histograf dari residu Normal P-P Plot of Regression Standardized Residual

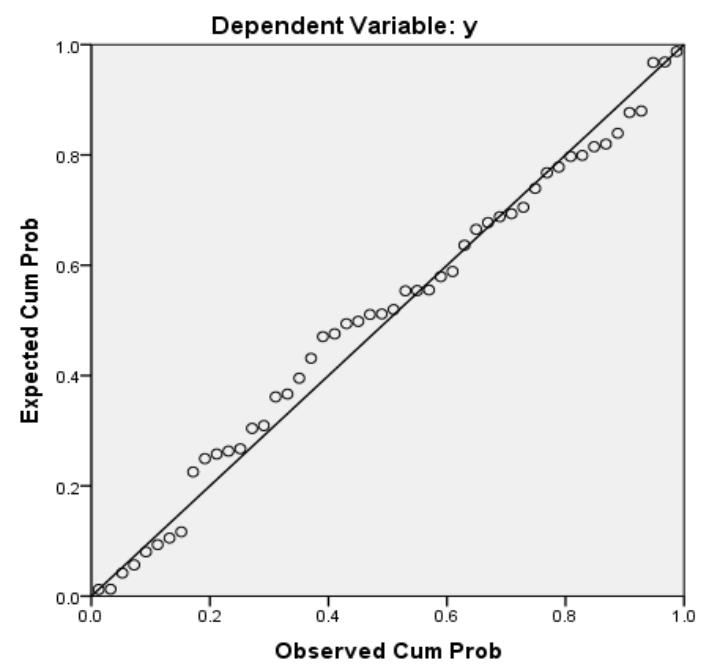

\section{Gambar 4.1}

\section{Uji Normalitas P-P Plot}

Dari gambar grafik diatas dapat diketahui bahwa titik - titik atau lingkaran kecil menyebar mengikuti garis diagonal atau mengikuti arah garis diagonal. Maka dapat 
disimpulkan bahwa data residu dari variabel Kepemimpinan Kerja (X1), Lingkungan Kerja (X2) dan Turnover Intention Karyawan (Y), data yang diteliti adalah data yang berdistribusi normal. Denga demikian uji normalitas menunjukkan terpenuhi asumsi Normalitas.

\section{Uji Heteroskedastisitas}

Pengujian ini bertujuan untuk menguji apakah terjadi ketidaksamaan varian dan residual satu pengamatan ke pengamatan lain dalam model regresi. Dari gambar Scatterplot dibawah, terlihat bahwa titik - titik menyebar secara acak, baik di bagian atas angka 0 atau bagian bawah angka 0 dari sumbu vertical atau sumbu Y. Dengan demikian dapat disimpulkan bahwa tidak terjadi Heteroskedastisitas dalam model regresi ini.

Scatterplot

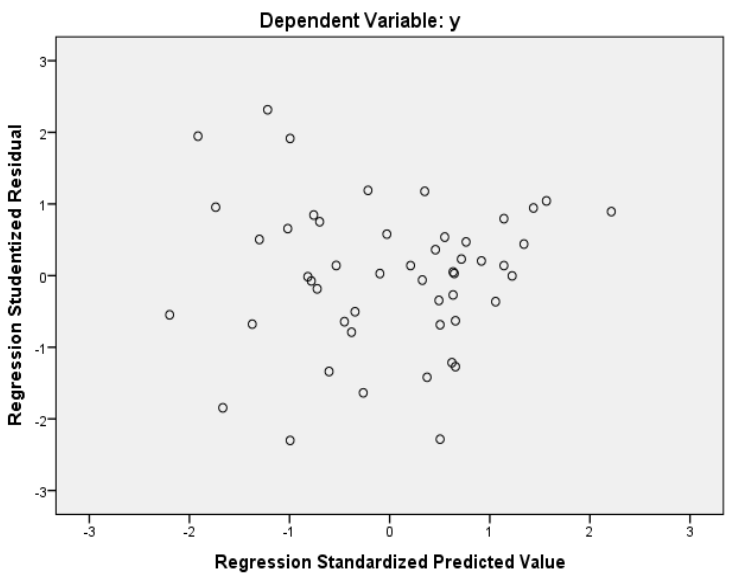

Gambar 4.2

Scatterplot Uji Heteroskedastisitas

\section{Uji Multikolinieritas}

Uji Multikolinieritas bertujuan untuk menguji apakah pada model regresi ditemukan adanya korelasi antara variabel bebas (independent variable).

Tabel 4.2

Uji Multikolineritas

Coefficients $^{\mathrm{a}}$

\begin{tabular}{|c|c|c|c|c|c|c|c|}
\hline \multirow[b]{2}{*}{ Model } & \multicolumn{2}{|c|}{$\begin{array}{l}\text { Unstandardized } \\
\text { Coefficients }\end{array}$} & \multirow{2}{*}{$\begin{array}{c}\begin{array}{c}\text { Standardized } \\
\text { Coefficients }\end{array} \\
\text { Beta }\end{array}$} & \multirow[b]{2}{*}{$\mathrm{t}$} & \multirow[b]{2}{*}{ Sig. } & \multicolumn{2}{|c|}{$\begin{array}{c}\text { Collinearity } \\
\text { Statistics }\end{array}$} \\
\hline & $\mathrm{B}$ & Std. Error & & & & Tolerance & VIF \\
\hline (Constant) & 6.377 & 5.043 & & 1.265 & .212 & & \\
\hline$x 1$ & .064 & .104 & .045 & .614 & .542 & .994 & 1.006 \\
\hline$x 2$ & .761 & .064 & .868 & 11.860 & .000 & .994 & 1.006 \\
\hline
\end{tabular}

a. Dependent Variable: $y$

Sumber : Output data pengolahan SPSS 22

Dari tabel coefficient yang diperoleh diatas, dapat diketahui bahwa nilai VIF untuk Kepemimpinan Kerja sebesar 1,006, dan nilai untuk Lingkungan Kerja adalah sebesar 1,006. Yang artinya, nilai VIF lebih kecil dari pada 10. Dan dapat disimpulkan bahwa tidak terjadi gejala Multikolinieritas diantara variabel bebas. 


\section{Hasil Uji Hipotesis}

\section{Pengaruh Kepemimpinan Kerja (X1) terhadap Turnover Intention Karyawan (Y)}

Tabel 4.3

Uji Parsial (Uji T) Variabel Kepemimpinan terhadap Turnover Intention Karyawan

\begin{tabular}{|c|c|c|c|c|c|c|}
\hline \multicolumn{7}{|c|}{ Coefficients $^{\mathrm{a}}$} \\
\hline & \multirow[b]{2}{*}{ Model } & \multicolumn{2}{|c|}{ Unstandardized Coefficients } & \multirow{2}{*}{$\begin{array}{c}\text { Standardized } \\
\text { Coefficients } \\
\text { Beta } \\
\end{array}$} & \multirow[b]{2}{*}{$t$} & \multirow[b]{2}{*}{ Siq. } \\
\hline & & B & Std. Error & & & \\
\hline \multirow[t]{2}{*}{1} & (Constant) & 6.377 & 5.043 & & 1.265 & .212 \\
\hline & Kepemimpinan & .064 & .104 & .045 & .614 & .542 \\
\hline
\end{tabular}

Sumber: Output data pengolahan SPSS 22

Berdasarkan perhitungan SPSS 22, maka nilai t hitung untuk variabel Kepemimpinan Kerja (X1) terhadap Turnover Intention Karyawan (Y) adalah sebesar 0,614, sedangkan nilai $\mathrm{t}$ tabel untuk $\mathrm{n}=47$ adalah sebesar 2,012. Jadi dikarenakan nilai $\mathrm{t}$ hitung $<\mathrm{t}$ tabel, yaitu $0,614<2,012$ dapat disimpulkan bahwa secara parsial variabel Kepemimpinan Kerja (X1) tidak mempunyai pengaruh terhadap variabel Turnover Intention Karyawan. Nilai probabilitas (signifikasi) adalah 0,542 yaitu berada diatas 0,050 dengan demikian Ha1 ditolak, serta disimpulkan bahwa tidak terdapat pengaruh yang positif dan signifikan antara variabel Kepemimpinan Kerja (X1) terhadap variabel Turnover Intention Karyawan (Y). Untuk skor rata-rata keseluruhan variabel Kepemimpinan Kerja adalah 4,224 berada di rentan skala 4,21 - 5,00, hal ini menunjukkan respon dari para responden terhadap pernyataan yang diajukan untuk variabel Kepemimpinan Kerja secara keseluruhan memilih menjawab sangat setuju dengan interpretasi skor tinggi.

2. Pengaruh Lingkungan Kerja (X2) terhadap Turnover Intention Karyawan (Y)

Tabel 4.4

Uji Parsial (Uji T) Uji Parsial (Uji T) Variabel Lingkungan Kerja terhadap Turnover Intention Karyawan

\begin{tabular}{|c|c|c|c|c|c|c|}
\hline \multicolumn{7}{|c|}{ Coefficients $^{\mathrm{a}}$} \\
\hline \multirow{2}{*}{\multicolumn{2}{|c|}{ Model }} & \multicolumn{2}{|c|}{ Unstandardized Coefficients } & \multirow{2}{*}{$\begin{array}{c}\begin{array}{c}\text { Standardized } \\
\text { Coefficients }\end{array} \\
\text { Beta } \\
\end{array}$} & \multirow[b]{2}{*}{$\mathrm{t}$} & \multirow[b]{2}{*}{ Siq. } \\
\hline & & $\mathrm{B}$ & Std. Error & & & \\
\hline \multirow[t]{2}{*}{1} & (Constant) & 6.377 & 5.043 & & 1.265 & .212 \\
\hline & $\begin{array}{c}\text { Lingkungan } \\
\text { Keria }\end{array}$ & .761 & .064 & .868 & 11.860 & .000 \\
\hline
\end{tabular}

Dependent Variable: Turnover Intention Karyawan

Sumber: Output data pengolahan SPSS 22

Berdasarkan analisis hasil perhitungan SPSS Versi 22, maka nilai t hitung untuk variabel Lingkungan Kerja (X2) terhadap Turnover Intention Karyawan (Y) adalah sebesar 11,860, sedangkan niali $\mathrm{t}$ tabel untuk $\mathrm{n}=47$ adalah sebesar 2,012. Jadi dikarenakan nilai $\mathrm{t}$ hitung $>\mathrm{t}$ tabel atau 11,860> 2,012 maka dapat disimpulkan bahwa secara parsial variabel Lingkungan Kerja (X2) memiliki pengaruh terhadap Turnover Intention Karyawan (Y). Nilai probabilitas (signifikasi) $=0,000$ yaitu berada dibawah 0,050 dengan demikian $\mathrm{Ha} 2$ diterima, serta dapat disimpulkan bahwa terdapat pengaruh yang sinifikan dan positif antara variabel Lingkungan Kerja (X2) terhadap Turnover Intention Karyawan (Y). Untuk skor rata-rata dari keseluruhan pernyataan variabel Lingkungan Kerja adalah 3,34 dan berada di rentan 2,61 - 3,40, hal ini menunjukkan respon dari para responden terhadap pernyataan yang diajukan untuk variabel Lingkungan Kerja adalah kurang baik dengan interpretasi rata-rata. 


\section{Pengaruh Kepemimpinan Kerja (X1) dan Lingkungan Kerja (X2) terhadap Turnover Intention Karyawan (Y)}

Tabel 4.5

Hasil Uji Simultan (Uji F)

Kepemimpinan Kerja dan Lingkungan Kerja terhadap Turnover Intention

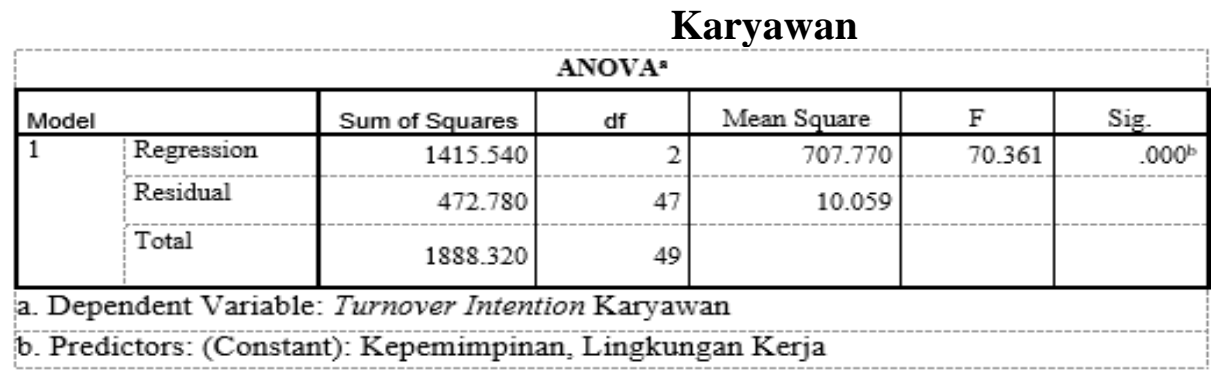

Sumber : Output Pengolahan SPSS 22

Berdasarkan analisis hasil perhitungan data pengaruh antara variabel Kepemimpinan Kerja (X1) dan variabel Lingkungan Kerja (X2) terhadap Turnover Intention Karyawan (Y) ditujukkan pada regresi linier berganda $Y$ ditujukkan oleh regresi linier berganda $\mathbf{Y}=\mathbf{6 , 3 7 7}$ $+\mathbf{0 , 0 6 4} \mathbf{X}_{1}+\mathbf{0 , 7 6 1} \mathbf{X}_{2}$ yang memiliki arti sebesar 6,377 meskipun tanpa adanya pengaruh variabel Kepemimpinan Kerja (X1) dan juga Lingkungan Kerja (X2), maka tingkat Turnover Intention (Y) sebesar 6,377.

Untuk koefisien regresi sebesar 0,064 pada variabel Kepemimpinan Kerja, merupakan merupakan koefisien arah regresi liniear yang positif, artinya bahwa setiap kenaikan Kepemimpinan Kerja (X1) sebesar satu satuan, maka Turnover Intention (Y) akan meningkat sebesar 0,064 dengan asumsi Lingkungan Kerja (X2) yang dianggap konstan. Sedangkan koefisien sebesar 0,761 pada variabel Lingkungan Kerja (X2), merupakan koefisien arah regresi linear yang positif, artinya bahwa setiap kenaikan Lingkungan Kerja (X2) sebesar satu satuan, maka Turnover Intention (Y) akan meningkat sebesar 0,761 dengan asumsi Kepemimpinan Kerja (X1) dianggap konstan.

Hasil pengaruh simultan variabel bebas terhadap variabel terikat diperoleh nilai $\mathrm{F}$ hitung $=70,361>$ nilai $\mathrm{F}$ tabel $=3,19$ sehingga Ho ditolak dan Ha diterima. Dengan kata lain "Terdapat pengaruh yang signifikan antara Kepemimpinan Kerja dan Lingkungan Kerja terhadap Turnover Intention Karyawan PT. Vanisa Rizki Jakarta Selatan”.

Nilai koefisien korelasi (R) sebesar 0,866. Hal ini menunjukkan bahwa terjadi hubungan yang sangat kuat antara Kepemimpinan Kerja dan Lingkungan Kerja terhadap Turnover Intention Karyawan. Sedangkan koefisien determinasi nilai R2 (R square) sebesar 0,750 atau $75 \%$ Kepemimpinan Kerja dan LIngkungan Kerja secara simultan memiliki kontribusi terhadap Turnover Intention Karyawan, sedangkan untuk sisanya sebesar 25\% ditentukan oleh variabel lain yang tidak diteliti pada penelitian ini.

\section{KESIMPULAN}

Berdasarkan hasil penelitian dan pembahasan yang telah diuraikan pada BAB IV (empat), maka dapat ditarik kesimpulan sebagai berikut :

1. Kepemimpinan Kerja pada PT. Vanisa Rizki sudah tergolong sangat baik yaitu $90 \%$ hasil tersebut didapatkan dari perhitungan jawaban responden sangat setuju ditambah dengan jawaban responden setuju $(\mathrm{SS}+\mathrm{S})$ atau dengan persamaan $(33 \%+57 \%)=90 \%$

2. Lingkungan Kerja pada PT. Vanisa Rizki sudah tergolong cukup yaitu 57\% yang mana hasil tersebut didapatkan dari perhitungan jawaban responden sangat setuju ditambah dengan jawaban responden setuju $(\mathrm{SS}+\mathrm{S})$ dengan persamaan $(21 \%+36 \%)=57 \%$.

3. Turnover Intention Karyawan pada PT. Vanisa Rizki sudah tergolong cukup yaitu 59\% yang hasilnya didapat dari perhitungan jawaban responden sangat setuju ditambah 
dengan perhitungan jawaban responden setuju $(\mathrm{SS}+\mathrm{S})$ dengan persamaan $(26 \%+33 \%)$ $=59 \%$.

4. Hasil analisa regresi linier berganda diperoleh $\mathbf{Y}=\mathbf{6 , 3 7 7}+\mathbf{0 , 0 6 4} \mathbf{X}_{\mathbf{1}}+\mathbf{0 , 7 6 1} \mathbf{X}_{\mathbf{2}}$ menyatakan meskipun tanpa adanya pengaruh variabel Kepemimpinan Kerja (X1) dan Lingkungan Kerja (X2), maka tingkat Turnover Intention (Y) sebesar 6,377. Hasil dari penelitian Koefisien Korelasi Berganda (R) sebesar 0,866, bahwa adanya hubungan yang sangat kuat antara Kepemimpinan Kerja dan Lingkungan Kerja terhadap Turnover Intention. Koefisien Determinasi atau Adjusted $\mathrm{R}$ Square diperoleh perhitungan sebesar 0,739 yang memiliki arti variant yang terjadi pada Turnover Intention (Y) adalah sebesar 0,750 atau $75 \%$ yang ditentukan oleh variabel Kepemimpinan Kerja dan Lingkungan Kerja, sedangkan sisanya atau sebesar $25 \%$ ditentukan oleh variabel lain yang tidak diteliti. Hasil pengujian simultan dari variabel bebas terhadap variabel terikat diperoleh nilai $\mathrm{F}$ hitung $=70,361>$ nilai $\mathrm{F}$ tabel $=3,19$ sehingga Ho ditolak dan Ha diterima. Dengan kata lain "Terdapat Pengaruh yang Signifikan antara Kepemimpinan Kerja dan Lingkungan Kerja terhadap Turnover Intention Karyawan pada PT. Vanisa Rizki Jakarta Selatan”.

\section{SARAN}

Berdasarkan hasil penelitian dan kesimpulan diatas dapat dikemukakan saran - saran sebagai berikut :

1. Dari hasil penelitian dan analisis jawaban kuisioner variabel Kepemimpinan Kerja, sebaiknya pemimpin dapat membina kerjasama dan hubungan baik dengan bawahan dalam pelaksanaan tugas dan tanggungjawab serta wewenang masing-masing.

2. Dari hasil penelitian dan analisis jawaban responden dari pengisian pernyataan kuisioner variabel Lingkungan Kerja, perusahaan perlu memperhatikan penjagaan yang ketat ditempat kerja, agar karyawan dapat merasa aman dan nyaman saat bekerja.

3. Dari hasil analisis dan penelitian jawaban responden dari pernyataan kuesioner variabel Turnover Intention, para karyawan harus mempertimbangkan kembali pemikiran untuk berhenti bekerja ataupun membandingkan pekerjaan lain.

4. Bagi penelitian selanjutnya diharapkan lebih mempersiapkan diri dalam proses pengambilan dan pengumpulan dari segala sesuatunya, sehingga penelitian dapat dilaksanakan dengan lebih baik dari sebelumnya.

\section{DAFTAR PUSTAKA}

Arianto, Nurmin. "Pengaruh Kualitas Pelayanan Terhadap Kepuasan Dan Loyalitas Pengunjung Dalam Menggunakan Jasa Hotel Rizen Kedaton Bogor." Jurnal Pemasaran Kompetitif 1.2 (2018).

Arianto, Nurmin. "Pengaruh Kualitas Pelayanan Dan Promosi Terhadap Kepuasan Konsumen Pada Alfamart Roda Hias Serpong. "Jurnal Ekonomi Efektif 2.1 (2019).

Abdullah, M. 2014. Manajemen dan Evaluasi Kinerja Karyawan. Yogyakarta : Penerbit Aswaja Pressindo.

Dharma, Cipta. 2013. "Hubungan Antara Turnover Intention Dengan KomitmenOrganisasional di PT. X Medan". Dalam Jurnal Ekonomi dan Bisnis Jurusan Administrasi Niaga Politeknik Negeri Medan, Volume 1 No. 2 Hal 1-9 Medan: Politeknik Negeri Medan.

Danang, Sunyoto. 2012. Manajemen Sumber Daya Manusia. Jakarta: PT Buku Seru.

Emeka Mbah, Samuel \& C.O. Ikemefuna, 2012. Job Satisfaction and Employees' Turnover Intentions in Total Nigeria p;c. In Lagos State, International Journal of Humanities and Social Science

Hasibuan, Malayu S. P,. 2012, Manajemen Sumber Daya Manusia (cetakan keenam belas), Jakarta : PT. Bumi Aksara. 
Nuraini, T. 2013. Manajemen Sumber Daya Manusia, Yayasan Aini Syam: Pekanbaru.

Rivai, Veithzal dan Deddy Mulyadi. 2012. Kepemimpinan dan Perilaku Organisasi. Edisi Ketiga. Jakarta : PT. Rajagrafindo Persada.

Sapre dalam Usman.2013. Manajemen. Jakarta : Erlangga.

Sedarmayanti. (2011). Manajemen Sumber Daya Manusia, Reformasi Birokrasi dan Manajemen Pegawai Negeri Sipil (cetakan kelima). Bandung : PT. Refika Aditama.

Sedarmayanti, 2012. Manajemen Sumber Daya Manusia. Jakarta : Refika Aditama Eresco.

Sudaryono. (2014). Budaya \& Perilaku Organisasi, Edisi Pertama. Jakarta: Lentera Ilmu Cendekia.

Sugiyono. (2012). Metode Penelitian Kuantitatif Kualitatif Dan R\&D. Alfabeta. Bandung. 